\title{
지구촌 빈곤감축을 위한 시민사회의 노력
}

\author{
한재광 ODA Watch 사무국장
}

\section{목차}

I. 서론

II. 빈곤감축을 위한 국제개발협력의 역사적 흐름과 시민사회

III. 빈곤감축을 위한 국제 시민사회의 주요 활동 동향

IV. 결론 : 한국시민사회에의 시사점과 과제

\section{I. 서론}

개발도상국의 빈곤감축 이슈는 오랜 기간 동안 국제사회가 해결하기 위한 주요 과제로 존재해왔다. 빈곤의 문제는 1990 년대 이후 세계화의 심화로 인한 양극화와 함께 불평등, 성차별, 평화와 안보, HIV/AIDS 및 보건, 인권과 거버넌스, 인간안보, 국제이주 등 여러 다양한 이슈들과 깊이 연결되 어 보다 복잡한 양상으로 전개되고 있다. 최근 서울에서 개최된 G20정상회담은 '경제성장 중심의 개발'1)을 통해 지구촌의 빈곤문제를 해결 한다는 접근법을 강조하였다. 그러나 이러한 접근법에 대해 세계 시민사회는 선뜻 충분한 동의를 하지 못하고 있다. 빈곤감축에는 GNP의 성장을 통한 해결 즉, 경제적 접근법외에 인권, 불평등, 양성평등, 거버넌스 등 빈곤의 다면적 성격을 고려한 다양한 접근법이 필요하기 때문이다. 그래서 국제사회가 빈곤감축을 개발협력의 중요한 목표로 규 정하고 이를 달성하기 위해 대대적인 공동의 노력을 취해왔음에도 불구하고 빈곤의 복잡 다양한

1) 이성훈. 서울 G20 정상회의와 개발 - 절반의 '성공'이자 '실패' ODA Watch Letter 2010 http://www. odawatch. net/articlesth/7652 (2010년 12월 3일 방문) 
현실을 제대로 고려하지 못함으로써 기대한 만큼의 성과를 거두지 못해왔다.

이에, 본 글에서는 빈곤감축을 위한 국제사회의 행위자 중 시민사회의 다양한 움직임을 소개하고 자 한다. 세계 시민사회는 빈곤감축에 있어 정부기관 및 국제기구가 집중하는 것과는 다른 인식과 방향의 노력을 전개하고 있다. 빈곤감축을 위해 세계 시민사회가 강조하고 집중하는 내용을 소개 하는 본 글을 통해, 현 시대의 국제개발협력의 흐름을 더욱 균형 있게 파악할 수 있을 것이다. 또 한 이는 국제개발협력에 본격적으로 참여하고 있는 한국 시민사회에도 깊이 생각해볼 만한 시사점 을 줄 것이다.

\section{II. 빈곤감축을 위한 국제개발협력의 역사적 흐름과 시민사회}

빈곤감축은 국제개발협력의 오래된 핵심 이슈이다. 전후복구가 중심이 되었던 2차 세계대전의 종 식 이후를 거쳐, 1950 년대와 1960년대 선진국들은 지속적인 경제성장을 바탕으로 개도국에 주로 외환원조를 실시하여 공업화를 지원하였다. 이 시기에는 성장과 근대화를 통해서 빈곤과 불평등의 문제가 빠르게 해결 될 것이라는 믿음이 가득했었고2) 많은 선진공여국이 개도국에 대한 지원을 지지하는 개발원조의 '영광의 시기(glory years)'로 평가 되었다. ${ }^{3)} 1960$ 년대는 선진국과 개도국의 경제격차가 '남북문제'로 표현되어 이를 해결하는 것이 국제개발의 중심 이슈로 부각되었다. 그러 나 1970년대 초반까지 개발원조는 빈곤에 대한 명백한 언급을 하지 않았다. 1969년 전 캐나다 수 상인 피어슨(Pearson)이 작성한 '개발을 위한 파트너십' 즉 피어슨 보고서(Pearson Commission Report)4)에서도 빈곤감축에 대한 언급이 전혀 없을 정도였다. OECD/DAC는 1960년대 말에야 빈 곤과 실업에 대한 논의를 처음으로 시작하였다. 국제기구와 정부기관 중심의 국제원조사회는 1970 년대 초반까지 빈곤을 이를 개발원조와 직접 연결시키는 논의까지로 발전시키지는 못했다. 개발 $\mathrm{NGO}$ 들을 중심으로 하는 세계 시민사회는 1940년대와 1950년대에는 난민캠프, 급식소, 병원 등에 서 전쟁피해자를 지원하는 구호중심의 사업을 수행하였다. 이후 개발NGO들은 1960년대 들어서 빈곤의 원인에 접근하는 개발사업에 중점을 두고 마을과 슬럼가 등지에서 사업을 수행하였다.5)

1970년대 들어 기존의 경제성장 중심의 국제개발 접근 방식에 대한 문제가 제기되며, 새로운 모색

2) Finn Trap, "Aid and Development". SWEDISH ECONOMIC POLICY REVIEW 13.

3) Roger C. Riddle. Does Foreign Aid Really Work?(New York: Oxford University), p 27.

4) 피어슨 보고서는 1968년 World Bank가 전 캐나다 수상인 피어슨에게 위탁하여 제작한 보고서로 ODA가 무엇인가에 대해 언급하였고, GNP의 $0.7 \%$ 를 제공할 것 등 개발원조에 대한 중요한 내용을 제시하였다.

5) Clark. John, Democratizing Development: The Role of Voluntary Organizations(Connecticut: Kumarian Press. 1991), p 30. 
의 필요성과 대안들이 제시되었다. World Bank 총재인 맥나마라(Robert McNamara)와 UN의 기 여로 빈곤 개념에 기반한 개발의 방법들이 제시되었다. 즉, GNP의 증대로 대표되는 이전의 성장 접근 방식 외에 고용, 소득분배, 빈곤감축 등이 주요하게 다루어지기 시작한 것이다 구체적으로 는 과거의 경제 인프라 건설 위주의 개발 방식에서 도시와 농촌지역의 빈곤감축, 의식주, 교육, 위생 등 인간기본욕구(basic human needs, BHN)충족 등의 방식으로 개발원조가 진행되었다. 이 시기에 개발NGO들은 기존의 교육, 의료보건사업 등 전통적인 사업의 범위를 넘어서 지역개발, 대 부와 저축, 정규 교육기관 외에서의 기술훈련 등을 수행했다. 또한 선진국의 시민사회는 개도국의 $\mathrm{NGO}$ 를 통한 사업수행을 본격적으로 수행하였으며, 자국의 시민 및 학생들을 대상으로 하는 개도 국의 빈곤의 현실을 알리고, 개도국에 대한 지원을 증대하고 자하는 목적으로 선진국의 정부와 기 업들을 대상으로 대중캠페인과 의회 로비 등 옹호활동을 하기 시작했다. ${ }^{6)}$

1980년대에 들어서 공여국들은 점차 '빈곤의 다면성'을 인식하고, 여성과 주변화된 취약계층의 참 여개발(participatory development)을 통한 다양한 개발사업을 진행하기 시작했다. 그러나 1973 년과 1979년 두 차례의 석유파동을 겪으면서 국제사회는 신자유주의 노선의 구조조정(structural adjustment)을 개발원조의 중심전략으로 채택하였다. 이는 대외수지균형, 재정 및 금융균형, 이자 율에 대한 통제철폐 등의 경제정책을 통해 파트너 국가의 경쟁력을 갖추는 급진적인 구조조정을 중심 내용으로 하는 것이다. 그러나 이러한 국제개발협력의 변화가 개발NGO들의 활동에는 도리 어 기회로 작용했다. 이 시기에는 첫째, 국제개발협력에 있어 개발 $\mathrm{NGO}$ 들의 참여를 강조하는 연구 가 증대하였으며 둘째, '가장 빈곤한 자들'과 함께 일하는 능력과 헌신성을 가진 개발NGO들에 대 한 요구가 담겨진 정책문건들의 발간이 증대하였다. ${ }^{7)}$ 셋째, 과거 20 여 년간 개발담론을 주도하던 '근대화이론'과 '종속이론'이 그 과거의 영향력을 잃어버린 시대적 상황에서, $\mathrm{NGO}$ 는 새로운 이론 과 실제를 창출 할 수 있는 이론적 현실적 대안적 사상의 원천이자 유용한 행위자로 부각되었다. 넷째로, 빈곤감축에 실패하고 관료화와 부패 증대를 불러오는 등 '정부의 실패'가, 개발 $\mathrm{NGO}$ 를 대 안으로 등장케 하는 환경을 제공하였다. 다섯째로 양성평등, 환경 및 사회개발의 중요성 등 개발 $\mathrm{NGO}$ 가 정부가 집중하지 않는 이러한 새로운 논의들을 적극적으로 제공하였다. 마지막 여섯째로, 1989 년 냉전의 종식은 개발NGO들의 활동영역이 확대되는 큰 기회를 제공했다. 많은 개발NGO들 이 '체제전환국'의 발전을 위한 다양한 새로운 형태의 사업을 수행하게 된 것이다. ${ }^{8)}$ 이러한 다양 한 요인들로 인해 개발 $\mathrm{NGO}$ 들에 대한 인지도와 정부, 재단, 자발적 후원금이 점차 증대되었다. 개 발NGO들의 사업규모는 1982년 23억 달러에서 1992년 60억 달러로 3 배 정도 증대하였으며, 같은

6) Clark. Ibid 31

7) Riddle, Ibid. 37

8) Lewis David., and Nazneen Kanji, Non-Governmental Organizations and Development (NewYork: Routledge, 2009), pp. 34-43. 
시기에 개발NGO를 통한 $\mathrm{ODA}$ 지원도 두 배 가량 증대하였다. 이 시기에 몇몇 개발NGO들은 기존에 시행해온 직접사업수행(service delivery)외에 빈곤한 자들에게 부정적인 영향을 미치는 구조조정 정책에 대한 우려로 정부와 국제기구 등에 대한 정책옹호(advocacy)사업을 전개하기 시작했다. ${ }^{9)}$

1990년대는 냉전 종식과 '원조피로현상(aid fatigue)' 그리고 선진공여국의 경제악화 등의 이유로 공적개발원조(Official Development Assistance, ODA)의 규모가 축소되었다. 또한, 이 시기에는 개발원조의 전제조건으로 파트너 국가의 국정관리와 행정체계를 개선해야 한다는 내용의 거버넌스 이슈를 비롯하여 환경, HIV/AIDS, 이주, 양성평등 등이 국제개발의 주요 의제로 제기되었다. 그러 나 무엇보다도 1990 년대의 가장 큰 특징은 '빈곤감축'이 20여년 만에 다시 개발원조의 중심 주제 로 '재발견(rediscovered)'되었다는 것이다. 10) 1990년대에 추진된 '신정책아젠다(new policy agenda)' 는 신자유주의적 경제정책과 결합하여 정부의 개발원조 정책에 비해 대안적이고 효율적이며, 민주 적인 절차를 강화시키는 잠재력을 가지고 굿거번너스에 기여하는 개발NGO 프로젝트를 만들어냈 다. 이 시기에 많은 북반구의 개발 $\mathrm{NGO}$ 들은 개도국에서 직접 사업을 수행하는 방식으로부터 남반 구 $\mathrm{NGO}$ 들을 대상으로 직접 자금지원(direct funding)과 조직 지원(organizational support)을 하는 방식으로 전환하였다. 많은 북반구 개발NGO가 공여자가 되었고, 남반구 $\mathrm{NGO}$ 들과의 관계에 대해 재 정의를 내렸다. 이때 파트너십, 역량 강화 등의 개념들이 사용하기 시작했다. ${ }^{11)} 1990$ 년대 개발NGO는 국제정세의 변화에 따라 전 유고연방, 동부아프리카와 같은 분쟁지역에서 안정을 이 루고자 하는 서구 국가들의 정책적 수단으로 활용되기도 했다. 이 같은 상황에 대해 알란 파울러 (Alan Fowler)는 개발NGO들이 더 이상 장기적 개발사업을 하지 않고 지구적 '무료급식소의 국자 (ladles for the global soup kitchen)'역할만을 수행했다고 비판하였다. 또한 개발NGO를 포함하 는 국제시민사회는 1996년 기념비적인 활동을 수행했는데 바로 ‘쥬빌리(Jubilee)2000'이다. 이 운 동은 고채무국의 부채를 탕감하자는 부채탕감운동으로 2000년 까지 진행 되어 큰 성과를 거두었 다. 이는 직접적인 개발사업수행 외에 정책개입운동을 통해 빈곤감축에 기여하는 세계 시민사회의 대표적인 활동이다. 이러한 시대적 흐름 가운데 1990 년대에 들어서 다수의 국제개발기구들이 빈곤 감축을 개발원조의 주요 의제로 다루는 문건들을 발간하여 국제 규범과 가이드라인들을 제공하였 다. 1996년 개최된 OECD/DAC 고위급 회담은 '21세기를 향하여 : 개발협력을 통한 공헌(Shaping the 21st Century: The Contribution of Development Co-operation)'을 국제개발을 위한 전략문서 로 채택하였다. 이 문서는 국제개발을 위해 경제적 복지, 사회개발 그리고 환경적 지속가능성과 혁신 등 세 가지 분야로 구성된 7가지 목표인 '국제개발목표(IDGs: International Development

9) Riddle, Ibid

10) Riddle, Ibid

11) Lewis. David. "Development NGOs and the Challenge of Partnership: Changing Relations between North and South." Social Policy \& ADMINISTRATION. Vol 32, No.5, (1998 December): 502-509. 
Goals')를 제공하였고 이를 달성하기 위해서는 주인의식, 파트너십, 공여국의 원조일치가 중요하다 는 점을 강조하였다. ${ }^{12)}$ 이 7 가지 국제개발목표는 2000년 발표된 '새천년개발목표(MDGs : Millenium Development Goals)'의 기초가 되었다. 이 회의를 통해 발간된 '빈곤감축 가이드라인(Guidelines on Poverty Reduction)'은 빈곤감축을 위한 주요 정책으로 빈곤층을 위한 성장, 빈곤층 역량강화 와 인권, 거버넌스, 인간개발을 위한 기초적 사회서비스, 인간안보, 성주류화와 양성평등, 환경적 지속가능성을 제시하였다.

2000 년대 들어 국제사회는 MDGs달성을 목표로 하여 ODA의 양적증대를 위해 노력을 했으며, 한 쪽으로는 원조의 효과성(aid effectiveness) 제고를 강조해왔다. 2005년 파리에서 개최된 3차 원조 효과성고위급회의는 '파리선언'을 도출하였고 이는 2010년 현재까지 국제개발협력의 중요 기준이 되고 있다. 세계시민사회는 1990년대부터 시작하여 2000년대 이후 국제사회에서 본격적으로 정책 개입활동을 통해 국제개발협력 정책에 영향을 주기 시작했다. 세계시민사회는 1992년 리우데자네 이루 유엔환경개발회의, 1995 년 코펜하겐 사회개발세계정상회의와 북경 세계여성대회, 2000 년 요 하네스버그 지속가능발전 사회개발정상회의 등 각종 국제개발 관련 국제회의에 적극적으로 참여하 였다. 여성단체, 인권단체, 노동운동단체 및 개발 $\mathrm{NGO}$ 들을 포함하는 국제시민사회는 OECD/DAC의 '원조효과성에 관한 고위급회담'을 국제개발협력 정책 개혁을 위한 핵심적인 공간으로 인식하고, 지속적인 정책개입을 통해 영향을 미치고 있다. 세계시민사회는 2008년 아크라 3차 원조효과성고 위급회의에서는 회의 구성에 직접 참여하였으며, 2011년 부산 4차 원조효과성고위급회의를 위한 정 책개입 작업을 활발하게 진행하고 있다. $\mathrm{OECD} / \mathrm{DAC}$ 를 위시로 하여 선진공여국 정부들도 시민사 회를 중요한 행위자 인식하고 보다 선진적인 국제개발협력 체제를 조성하기 위해 협력하고 있다.

이상과 같이 국제 시민사회는 지난 1,2 차 세계대전 이후 주로 구호와 개발사업 등 직접적인 사업 수행을 통해 국제개발협력에 중요한 행위자로 참여해왔다. 그리고 1990년대 이후부터 빈곤감축을 위한 기존의 전통적인 직접사업 수행 이외에도 정책연구, 로비, 옹호, 캠페인 등의 활동을 전개하 며 국제개발협력체제에 본격적인 정책적 개입을 하고 있다.

12) OECD, Shaping the 21st Century : The Contribution of Development Cooperation. (Paris: OECD, 1996) 


\section{III. 빈곤감축을 위한 국제 시민사회의 주요 활동 동향}

\section{1. 개발NGO의 직접사업수행(Service delivery)}

개발NGO를 중심으로 세계시민사회는 개도국에서 다양한 개발사업을 수행하여 빈곤감축에 직접적 으로 기여하고 있다. 재정 규모를 기준으로 개발NGO의 성장을 본다면 아래〈표1〉과 같이 1991 1992년 선진공여국의 ODA자금 대비 9.7\%에서 2007년에는 $17.8 \%$ 에 이르는 규모의 자금을 직접 집행할 정도로 중요한 공여자로 성장하였다.

〈표 1〉OECD/DAC 회원국 및 NGO의 원조 규모 변화

(단위: 백만 USD)

\begin{tabular}{|c|c|c|c|c|c|c|c|}
\hline & $1991-92$ 평균 & $1996-97$ 평균 & 2003 & 2004 & 2005 & 2006 & 2007 \\
\hline ODA 자금 & 58,453 & 52,028 & 69,065 & 79,432 & 107,078 & 104,370 & 103,491 \\
\hline NGO 자체지금 & 5,704 & 5,480 & 10,239 & 11,320 & 14,712 & 14,648 & 18,508 \\
\hline $\begin{array}{c}\text { ODA대비 } \\
\text { NGO 집행자금 }\end{array}$ & $9.7 \%$ & $10.5 \%$ & $14.8 \%$ & $14.2 \%$ & $13.7 \%$ & $14 \%$ & $17.8 \%$ \\
\hline
\end{tabular}

출처: OECD 홈페0|지 hhttp://www.oecd.org/document/9/0,3343,en_2649_34447_1893129_1_1_11,00.html서 재구성

이러한 개발 $\mathrm{NGO}$ 의 성장에 대해 2008년 아크라 3 차 원조효과성고위급회의에서는 국제개발협력에 참여하는 기존의 개발 $\mathrm{NGO}$ 를 포함한 종교단체, 노조, 여성단체 등의 시민사회단체를 $\mathrm{CSO}$ (Civil Society Organization)로 총칭하며, 주요 '독립적인 원조공여자'로 인정하였으며, 그 역할과 효과 성을 강조하였다. ${ }^{13)}$

다음은 국제사회에서 큰 영향력을 발휘하는 각기 다른 성격을 가진 대표적 개발NGO들의 최근 사 업내용을 소개하는 내용이다. 네 개의 개발NGO는 각기 개발NGO 중 가장 오래된 역사를 가지고 있으며, 아동분야에 특화되어있는 Save the Children과 다양한 개발 및 구호사업을 수행하면서도 Jubliee 2000운동 주도, G20 대응 등 전 세계적인 국제개발협력 정책개입운동을 주도해온 OXFAM, 개발협력사업을 수행하면서도 꾸준히 개발정책운동을 진행해온 Action Aid, 그리고 대표적인 기 독교 개발NGO로 영향력 있는 활동을 해온 World Vision이다. 이러한 네 단체의 활동과 주요전략 을 파악함으로써, 빈곤감축과 관련하여 개발 $\mathrm{NGO}$ 들의 최근의 중점사항과 방향 및 구체적인 활동 동향을 파악할 수 있다.

13) http://siteresources, worldbank. org/ACCRAEXT/Resources/4700790-1217425866038/AAA-4-SEPTEMBER-FINAL -16h00.pdf (2010년 11월 30일 방문) 


\section{1) Save the Children}

Save the Children은 1919년 설립된 개발NGO로, “전 세계의 모든 아동이 생존하고 보호받으며 발전과 참여를 할 권리를 보유하고 있다”는 비전을 가지고 있다. 이 단체는 29개 국가 별 Save the Children이 협력하여 전 세계의 120 개국에서 활동을 하고 있다. 전통적으로 사회의 가장 약 자인 아동을 주 대상으로 활동하는 있으며, 아동보호와 아동권리증진 사업을 위시로 하여 빈곤감 축, 재난위험완화, 교육, 긴급구호, 건강, 식량위기, 캠페인 등의 사업을 수행하고 있다. ${ }^{14)}$ Save the Children은 2010-2015년 동안 주요하게 추진할 전략의 일환으로 2009년 9월 'EVERY ONE' 캠페인을 시작하였다. 이는 5 세 이하의 영유아가 막을 수 있는 원인의 질병으로 사망하지 않도록 돕는 것을 목적으로 하는 캠페인이다. ${ }^{15)}$ 'EVERY ONE' 캠페인은 MDGs 목표 4의 달성을 목표로 설정되고 수행되는 것으로 29 개의 국가별 Save the Children은 구체적이고 다양한 사업을 수행하 고 있다.

이와 같이 Save the Children은 최약자인 아동을 위한 다양한 직접적인 사업 수행에 중점을 두고 활동을 하고 있으며, 동시에 아동권리를 지키기 위한 정책옹호 활동을 수행한다.

\section{2) OXFAM}

1942년 영국에서 설립된 OXFAM은 14 개 국가별 OXFAM이 99개의 국가에서 활동16)하고 있는 국 제개발NGO이다. OXFAM은 타 국제개발NGO와 유사하게 구호, 개발, 교육, 옹호 사업을 수행하 고 있다. OXFAM은 2007년에서 2017년까지의 주요전략으로 'Demanding Justice'를 제시하였다. OXFAM은 'Demanding Justice'를 통해 “모든 이가 부정의와 빈곤을 종식시키기 위해 기본적인 권리를 충분히 활용할 수 있음을 보장해야한다”고 주장한다. 이는 OXFAM이 빈곤해결과 개발협력 을 결핍의 문제가 아닌 권리의 문제로 보고 있음을 잘 나타낸다. OXFAM은 이 전략을 달성하기 위해 '권리에 기반하는 접근법(rights-based approach)'을 활용한다. OXFAM은 'Demanding Justice'의 수행을 위해 5가지 핵심영역을 제시하고 이를 통해 궁극적으로 '인권에 기반하는 (human rights-based)'목표를 달성하고자 한다. 5가지 핵심영역은 첫째는 경제정의이고, 둘째 영 역은 가장 기본적인(quality essential)서비스에 대한 권리이다. 셋째 영역은 인도주의적 행동이 며, 넷째는 여성의 권리, 마지막 다섯째 영역은 시민권과 거버넌스이다. ${ }^{17)}$

14) http://www.savethechildren.net/alliance/what_we_do/campaign.html (2010년 11월 30일 방문)

15) Save the Children. 2009. Save the Children International Annual Review 2009.

16) www. oxfam,org(2010년 11월 30일 방문)

17) OXFAM, Demanding Justice. p. $2,5$. 
OXFAM은 전통적으로 종교성이나 자선사업이 아닌 '권리에 기반한 접근'을 하는 사회운동으로 국 제개발협력사업을 수행해왔다. 이런 맥락에서 OXFAM는 과거 1990년대 중반이후 진행 된 국제빛 탕감 정책운동인 'Jubilee 2000'을 주도하는 중심단체 중 하나로 활동 하였고, 최근 G20서울 정 상회담에 대응하는 세계시민사회의 활동에서 핵심적인 역할을 수행하였다. OXFAM은 빈곤의 문제 를 구조적인 이슈로 인식하고 이를 해결하기 위해 직접적인 사업수행과 동시에 정책적 차원에서 접근하고 있는 것이다.

\section{3) Action Aid}

1972 년에 설립된 Action Aid는 현재 42개 국가에서 활동하는 개발NGO이다. 이 단체는 "빈곤과 부정의가 없는 세계”를 추구한다. ${ }^{18)}$ 다음의 6가지 내용19)이 Action Aid 활동의 지향점과 내용을 잘 설명해 준다. 첫째, 불평등한 권력관계를 해결하고, 권리에기반하는 접근과 방법론을 강화하여 빈곤감축에 집중한다. 둘째, 교육과 식량지원 그리고 HIV/AIDS관련 활동을 강화한다. 셋째, 가난 하고 소외된 사람들을 위한 사회운동을 증대한다. 넷째, 여성권리와 양성평등을 위한 활동과 헌신 을 개선한다. 다섯째, 민주주의와 거버넌스 그리고 분쟁과 긴급상황에서의 인간안보 등의 이슈와 관련된 빈곤과 부정의를 다룬다. 여섯째, 지구적 수준에서 Action Aid의 영향, 재정자원을 증대하 여 조직의 국제화를 성공적으로 구축한다.

Action Aid는 지구적 빈곤의 문제를 부정의의 문제로 규정하며 이를 해결하기 위한 개발 및 구호 사업을 수행함에 있어 '권리에 기반하는 접근' 방식을 활용하고 있다. 또한 국제 원조체제를 개선 하는 정책개입활동에도 적극적으로 참여20)하고 있는 등 직접적인 개발 사업수행과 정책적 개입 즉 구조적인 접근을 동시에 수행하는 단체이다.

\section{4) World Vision}

World Vision은 1950년 설립된 기독교를 기반으로 전 세계의 100 여개국에서 활동하는 개발NGO 이다. World Vision은 비전선언문에서 “우리의 비전은 모든 어린이가 풍성한 삶을 누리는 것이며, 우리의 기도는 모든 사람이 이 비전을 실현하도록 하는 것입니다21)"라고 설명한다. World Vision 은 기본적으로 개발, 구호, 옹호사업을 수행한다. World Vision은 최근 개발사업을 수행함에 있어 'Child Well-being Outcomes'를 내세우고 있다. 이는 건강, 교육, 신앙과 이웃사랑(Children love

18) http://www.actionaid.org/main. aspx?PagelD=2 (2010년 11월 30일 방문)

19) Action Aid, RIGHTS TO END POVERTY ACTION AID INTERNATIONAL STRATEGY 2005/2010 (Johannesburg: Action Aid, 2005), p. 6

20) Action Aid International은 Better Aid의 회원단체로 활동하고 있다.

21) https://www.worldvision.or.kr/html/worldvision/mind01.asp (2010년 11월 30일 방문) 
God and their neighbours) 그리고 보호와 참여 등 네 개의 영역에서 월드비전의 비전과 미션을 구체적인 사업으로 실현하는 것을 의미한다. ${ }^{22)}$. 또한 World Vision은 최근 단일 이슈에 집중하는 지구적 캠페인으로는 첫 번째인 “Child Health Now"를 시작하였다. ${ }^{23)}$ 이는 MDGs 목표 4인 5세 미만 아동의 예방 가능한 사망률 감소를 위한 내용이다. 또한 World Vision은 부정의와 불공정한 체제가 가난한 이들에게 영향을 준다고 인식하고 가난한 이들이 이러한 부정의와 불평등을 종식시 키는 것을 주장하도록 돕는 옹호사업을 진행한다.

월드비전은 기독교를 기반으로 하고 있으며, 충분한 경험과 전문성을 가지고 구호와 개발 및 옹호 사업의 영역에서 다양한 사업을 수행하고 있다.

이와 같이 다양한 부분에서 지구촌의 빈곤문제 해결을 위해 활동하는 개발NGO들에 대해 긍정과 동시에 우려의 목소리가 존재한다. 원조규모와 독립적인 원조공여자로 인정을 한 아크라 3 차 원조 효과성고위급회의가 개발 $\mathrm{NGO}$ 들에 대한 긍정적 반응을 보여준다면, 부정적 반응은 학자들로부터 나왔다. 일군의 학자들이 개발NGO의 그 활동 방향에 대해 문제를 제기하였다. 영국 맨체스터 대 학의 개발학자들인 베빙톤(Bebbington), 히키(Hickey) 그리고 미틀린(Mitlin)은 다음과 같은 내용 의 문제를 제기한다. 이들은 개발 $\mathrm{NGO}$ 들이 개발사업을 수행함에 있어 한 사회의 정치, 경제 그리 고 사회적 관계를 조직하는 근본적인 발전의 방식을 고민하기 보다는, 효율적인 개발사업의 수행 과 같은 '관리'의 문제에 쉽게 관심을 가지고 이에 집중하는 것을 비판하였다. ${ }^{24)}$ 이는 개도국의 빈곤감축을 위한 직접적인 사업수행을 중심으로 국제개발협력에 참여하는 개발 $\mathrm{NGO}$ 들은 깊이 고 민해야 할 대목이다. 즉, '비용 효율적인 개발사업 수행자'인지 아니면 '구조적접근을 하는 대안개 발자'인지 그 정체성에 대한 문제제기이다.

\section{2. 세계 시민사회의 원조 정책개입 연대운동}

세계시민사회는 역사적으로 다양한 연대운동을 전개해 왔다. 여성, 노동, 평화 및 환경 등 제 분 야에서 세계 시민사회는 국제연대를 통해 정책개입을 하여 1996년에는 국제대인지뢰금지운동 (ICBL)이 국제대인지뢰금지협약을 이끌어내는데 결정적으로 기여하는 등 각 분야에서 구체적인 성과를 이루어냈다. 그중 개도국의 빈곤감축을 돕는 대표적인 정책운동이 1996년부터 2000년까지

22) http://www. wvi.org/wvi/WVIAR2009.nst/maindocs/D6DC795AC6FCFAA7882576DB007FC42D?opendocument (2010년 12월 7일 방문)

23) https://childhealthnow. com/docs/en/child-health-now-report.pdf (2010년 12월 7일 방문)

24) Bebbington, Hickey and Mitlin, Can NGOs Make a Difference?, The Challenge of Development Alternative. In Can NGOs Make a Difference?, ed. Bebbington, Anthony., J. Samuel Hickey and Diana C. Mitlin. (New York: Zed Books LTD 2008), p. 5-17. 
시행된 국제빚탕감운동인 ‘Jubilee 2000’이다. 이는 1996년 세계교회협의회(WCC)를 중심으로 한 많은 기독교 단체와 50 여 개국의 시민사회단체들이 결성한 연합운동이다. 이들은 'Drop the Debt' 을 구호로 하여, 외채부담으로 심각한 빈곤의 상태에서 벗어나지 못 하는 최빈국들의 부채를 탕감 하자는 캠페인을 진행하였다. 'Jubilee 2000 '은 최빈국의 빈곤의 원인을 물질적 결핍과 기술과 의 지의 부족에서 찾은 것이 아니다. 그들은 그 원인을 G7 및 국제통화기금(IMF), 세계은행(WB)등 선진국과 국제금융기관과 빈곤국들과 맺고 있는 채무관계에서 찾고, 그에 대한 문제를 제기하며 최빈국에 대한 빛탕감을 위한 정책운동을 전개했다. ${ }^{25)}$

세계시민사회는 2000년대 들어 원조체제와 구체적인 정책에 더욱 관심을 가지게 된다. 특별히 2000 년대 국제개발협력의 핵심 이슈인 '원조효과성'과 관련하여 세계시민사회는 연대운동체를 중 심으로 집중적인 운동을 수행하고 있다. 이중 가장 영향력 있고 대표적인 세 개의 세계시민사회의 연대운동을 소개한다. 이는 2008년 아크라 3차 원조효과성고위급회의 과정에서 구성된 'Better Aid' 와 'Open Forum on CSO Development Effectiveness(이하 Open Forum)' 그리고 오래전부터 공여국의 개발원조에 대한 비판적인 정책감시와 제안활동을 해온 'Realty of Aid'가 있다. 이 세 연대운동의 활동을 통해 현 시기 빈곤감축과 국제개발협력에 대한 국제시민사회의 큰 동향과 주요 내용을 확인할 수 있다.

\section{1) Better Aid}

원조효과성과 관련하여, 세계시민사회는 2005 년 파리 2 차 원조효과성고위급회의의 결과인 '파리선 언의' 제정 과정에 효과적으로 참여하지 못했다. 이에, 세계시민사회는 2008년 3차 아크라 원조효 과성고위급회의에서 회의의 준비 및 진행 과정과 그리고 사후 활동에 적극적으로 참여하였다. 시 민사회단체들은 3차 아크라 회의를 대응하는 과정에서 2007년 CSO Network를 결성했고, 이후 이를 기반으로 ISG(International CSO Steering Group)를 조직했다. 2008년 8월 88개국 325개 의 시민사회단체에서 600 여명이 아크라에서 개최된 시민사회포럼에 참여했으며, 9 월에 개최된 아 크라 3 차 원조효과성고위급회의에는 700 여개의 시민사회단체들이 참여했다. 세계 시민사회는 이 후 Better Aid Coordinating Group(BAGG)를 결성했고, 현재 이를 중심으로 2011년 부산 4차 원 조효과성고위급회의를 준비하고 있다. 현재 Better Aid는 $\mathrm{OECD} / \mathrm{DAC}$ 의 원조효과성작업반(WP-EFF) 과 집행위원회(executive committee)에 공식적으로 참여하고 있다. 이 단체는 32 개의 각국의 개 별단체가 아닌 시민사회연대체(platform)가 참여하는 형태로 활동한다.

25) 최빈국에 대한 아일랜드의 다자적 채무 100 퍼센트 폐지, 2005년에는 18 개 아프리카 국가들이 국제통화기금과 세계은 행, 아프리카개발은행에 지고 있는 부채 4 백억 달러에 대한 선진그룹(G8)의 100 퍼센트 탕감 합의를 이뤄냈다. 김나 리, ODA Watch Letter 11호,. http://www. odawatch,net/?mid=articlesth\&sort_index=readed_count\&order_type= asc\&page=5\&document_srl=1184 (2010년 12월 3일 방문) 
Better Aid는 현재의 국제개발협력 시스템으로는 지구상의 문제들을 해결하지 못한다고 주장한다. 국제사회가 집중하고 있는 원조효과성에 대해 Better Aid는 다음의 10가지 구체적인 비판을 한다. 첫째, Better Aid는 원조효과성을 원조관리와 사업수행에만 집중하는 '고도의 기술적인 아젠다'로 규정한다. 둘째는 원조효과성은 국제사회 및 개별국가 차원에서의 원조 규모와, 정책, 사업을 다 루는 데 있어 정보공유와 투명성이 부족하다는 것이다. 셋째, Better Aid는 파리선언이 각 개별 국가의 고유한 핵심적인 정치적, 사회적 및 경제적 도전들을 무시하고 있음을 지적한다. 넷째, 파 리선언과 아크라행동선언에서의 거버넌스 이슈는 공여자 중심의 결정사항을 따른 것이다. 여섯째, 파리선언은 원조의 수준을 제고하고 공여자의 조화(harmonization)와 일치(alignment)를 성취하 려는 노력의 과정에서 민주적 주인의식, 인권, 여성의 권리, 경제·사회·문화적 권리 등의 이슈는 소홀히 다룬다. 일곱째, Better Aid는 파리선언이 젠더이슈에 대해 무관심하며, 양성평등에 대해 매우 강조하지 않고, 고립된 목표로 다루고 있음을 지적한다. 여덟째, 아크라행동선언은 '품위있는 일자리(decent work)'이슈를 다루는 데 실패했다. 아홉째, 파리선언과 아크라행동선언은 ODA와 타 개발재원 동원정책과의 충분한 연계를 만드는데 실패했다. 열째, Better Aid는 파리선언 모니터링 계획이 큰 문제가 있는데, 이는 파리선언의 원칙의 실행을 측정하기 위한 독립적인 방법이 결여된 채 World Bank이 평가법에 의존하고 있다는 것이다. 또한 여기에는 민주적 주인의식이나 양성평 등을 측정하는 필수지표가 없으며, 아크라행동선언도 양성평등, 여성권리, 반부패, 시민사회참여 및 기타 국제적 협약에 참여한 국가들이 가지는 의무를 모니터링 할 수 있는 새로운 내용들을 결 여하고 있음을 지적한다. Better Aid는 또한 아크라행동선언이 파리선언과 개발성과의 영향에 관 해 효과적이고 적절한 독립적 모니터링, 평가시스템을 구성하는데 실패하고 있다고 지적한다. Better Aid는 원조효과성 논의가 기술적이며, 기존의 정부 중심의 담론에 의존하고 있으며, 근본 적인 접근을 하지 못하고 있다고 비판한다. ${ }^{26)}$

Better Aid는 2010년 1월 'Development Cooperation: Not Just Aid-Key issues: Accra, Seoul and beyond'라는 제목의 정책문서를 발간하였다. 이 보고서를 통해 Better Aid는 가난한 이들을 위한 지속가능한 진전을 성취하기 위해, 현 원조체제의 우선순위와 실행방식은 근본적으로 개혁되 어야 한다고 주장하였다. 그리고 이러한 변화는 '개발효과성'(development effectiveness)이 국제 개발협력을 주도한다는 원칙과 그 접근법에 의해 이행되어야 함을 강조하였다. 즉 Better Aid는 그동안 국제개발협력 체제에서 가장 중요한 핵심이슈로 논의 되어온 원조효과성을 대체하는 개념 으로 개발효과성을 제시한 것이다. Better Aid는 개발효과성이란 가난하고 주변부화 된 사람들의 삶을 개선하기 위한 원조를 포함한 개발행위자들의 활동들이 미치는 영향에 대한 것이라 규정한 다. 그리고 이는 빈곤과 불평등 그리고 주변부화(marginalization)의 근본적 원인과 증상들을 해

26) Better Aid, 2010, "Development effectiveness in development cooperation : a rights-based perspective", Policy Paper.p.2. 
결하는 지속가능한 변화를 촉진한다고 설명한다. ${ }^{27)}$ 또한 Better Aid는 개발효과성은 국제원조, 무 역, 금융시장, 외국직접투자(Foreign Direct Investment)와 부채를 포함한 모든 수준에서의 지구 적 거버넌스 체제의 중대한 변화를 요구한다고 주장한다. ${ }^{28)}$ 개발효과성의 주도를 위해, Better Aid는 아홉 개의 이슈들을 제시하였다. 첫째 이슈는 국제개발협력의 개혁을 위한 프레임웍으로서 의 개발효과성의 증진이며, 둘째는 원조체계(aid architecture)가 포괄적이고 다원적이며, 공평하 게 되도록 개혁하는 것이다. 셋째 이슈는 민주적 오너십, 국가시스템의 활용, 정책개선조건(policy conditionality)의 완화에 대한 현재의 공약들을 최대한 실행토록 함이다. 넷째 이슈는 양성평등과 여성의 권리 증진에 대한 기여이며, 다섯째 이슈는 지속가능한 발전을 위한 핵심 목표들로서 존엄 한 일자리(decent work) 창출과 공평한 경제발전을 장려하는 것이다. 여섯째 이슈는 민주적 오너 십과 참여를 가능케 하는 환경조성(enabling environment)이며, 일곱째 이슈는 국가수준에서의 개발효과성과 원조를 평가하는데 관련된 행위자를 확대하여 개발성과들에 대한 상호책임성을 개선 한다는 것이다. 여덟째 이슈는 공여자와 개도국 상호간 또 그들과 시민들 사이의 책임성과 원조의 효과성을 증대하기 위한 원조 투명성을 성취이고 마지막 아홉째 이슈는 개발에 영향력을 미치는 분야(원조, 농업, 금융, 무역, 투자, 이주 및 기타 정책들)에 대한 폭넓은 정책적 개혁을 통한 빈 곤과 불평등의 감소이다. Better Aid는 개발효과성으로의 전환을 위한 이상의 아홉 개의 이슈를 제기하며, 개발협력은 가난한 국가에 단순히 재정적 자원과 기술적 노하우를 제공하는 것이 아니 라고 주장한다. Better Aid는 개발협력을 외국원조, 외국자본과 기술 그리고 외부 시장에 대한 종 속을 심화시키는 저개발(underdevelopment)의 구조적 기반을 제거하는 데 목적을 두어야 한다고 주장한다. 또한 개발협력이 시민들이 자신들의 개발의 과정에 대해 주권을 발휘할 수 있도록 하는 조건을 만들도록 도와야 한다고 설명한다. 그리고 개발협력은 보통 사람들이 포괄적이고 참여적이 며 민주적인 새로운 경제적, 사회적, 정치적 그리고 문화적 제도를 창출하는 것을 지원해야 함을 강조한다. ${ }^{29)}$

Better Aid는 2010년 10월에 'Development effectiveness in development cooperation : a rightsbased perspective'를 발간하여 개발효과성에 대해 보다 분명한 입장을 밝혔다. Better Aid는 현 국제개발협력 체제는 단독으로 현존하는 또 지속적으로 발생하는 전 지구적 필요를 해결하지 못한 다고 주장한다. 이에, Better Aid는 새로운 개발협력을 위한 프레임웍을 구축하기 위해 다섯 개의 핵심사항을 제시하였다. 그 첫째는 인권에 기반한 접근이다. 둘째는 빈곤과 불평등의 근원을 제거 하는 일에 대한 참여이며, 셋째는 민주적이고 포괄적이며, 다양한 이해당사자가 함께하는 접근이

27) http://www. betteraid.org/en/glossary.html

28) BetterAid Coordinating Group, 2010, Making development cooperation just: Governance principles and pillars, Discussion Note. p. 2.

29) Better Aid, "Development Cooperation : Not Just Aid.". (Better Aid 2010).p 2-9. 
다. 넷째 사항은 국가의 발전 우선순위와 계획이 이전에 합의된 지구적, 지역적 협약(Beijing platform for Action, ILO Decent Work Agenda등)에 맞추어져야 하며, 다섯째 사항은 포괄적 개발과 공정한 지구적 거버넌스를 위한 정책일관성이 필요하다는 것이다. ${ }^{30)}$

지난 10 월 파리에서 개최된 $\mathrm{OECD} / \mathrm{DAC}$ 이 16 차 원조효과성작업반 회의에서는 2011년 부산 4차 원 조효과성고위급회의에서 파리선언과 아크라행동선언의 원조효과성 이행 성과를 주요하게 논의하고 동시에 개발효과성 논의도 의제에 포함하는 선으로 마무리 지어졌다. 이에, 개발효과성이 주요 의 제화가 되기를 기대했던 Better Aid를 위시로 한 국제시민사회는 그 결과에 큰 실망을 했다. ${ }^{31)}$ 이러한 상황 가운데 Better Aid는 4차 부산회의에서 개발효과성이 주요하게 다루어 질 수 있도록 지속적인 정책개입의 노력을 하고 있다.

\section{2) Open Forum}

원조체제에 대한 시민사회의 정책적 개입을 하는 Better Aid와는 달리 Open Forum은 CSO의 효 과성(CSO Effectiveness), 즉 시민사회단체의 개발효과성에 대한 논의를 주도 하고 있다. 이 논의는 Advisory Group on Civil Society and Aid Effectiveness(AG-CS)가 주도하여 시작되었다. AG$\mathrm{CS}$ 는 2007년 설립된, $\mathrm{CSO}$ 와 정부기관이 참여하는 이해관계자 그룹으로 2008년 아크라회의에서 국제사회의 원조효과성을 논의하고 합의를 만드는 과정에서 시민사회가 개입할 수 있는 기회를 확 보하는 것을 목표로 설립되었다. $\mathrm{AG}-\mathrm{CS}$ 는 3 차 아크라회의에서 진행된 원조효과성 논의의 과정에 대해 시민사회의 관점을 반영하려 노력했으며, 결과적으로 아크라행동선언(AAA : Accra Agenda for Action)에 CSO와 관련된 항목인 20조를 구성하는데 기여했다. 이후 AG-CS는 Open Forum for CSO Development Effectiveness(Open Forum)로 활동을 지속하고 있다. ${ }^{32)}$

Open Forum은 각국의 $\mathrm{CSO}$ 들이 더욱 효과적으로 개발에 기여하기 위해 다루어야 할 주제들에 대한 논의를 진행하고, 그 결과를 바탕으로 한 합의의 과정을 상향식(bottom-up)으로 진행한다. 이 과정 에는 전 세계의 $\mathrm{CSO}$ 들이 참여하였는데, 사하라이남 아프리카에서 15 개국이 '국가별회의(national consultation)'를 개최했으며, 라틴아메리카와 서인도제도지역에서 12 개국이 참여했다. 북미에서는 미국과 캐나다 2개국이, 남태평양지역에서는 호주, 뉴질랜드, 피지와 통가 및 도서국가들이 국가 별회의를 개최했다. 유럽에서는 19 개 국가들이 참여했으며, 아시아에서는 12 개 국가가 북아프리카

30) Better Aid, "Development effectiveness in development cooperation: a rights-based perspective"(Better Aid 2010).pp. 1-9.

31) 홍지영, ODA Watch Letter. http://www. odawatch.net/?mid=articlesth\&page=2\&document_srl=7297 (2010년 12월 1일 방문)

32) 김혜경. 「국제시민사회 이슈와 한국시민사회의 대응과제」.제 5회 지구촌포럼 자료 ODA Watch. (2009년 11월 19일) 
지역에서는 3 개 국가가 참여하였다. ${ }^{33)}$ 전 세계적으로 총 63 개 국가의 시민사회단체가 이 과정에 참여한 것이다. 이후 지역별로 '지역별회의(regional consultation)'를 개최해 각 국가별회의에서 도출된 내용을 기본으로, 2010년 9월 터키 이스탄불에서 개최된 '세계총회(global assembly)'에서 $\mathrm{CSO}$ 의 개발효과성을 위한 8 개의 원칙을 제정했다. 첫째 원칙은 $\mathrm{CSO}$ 들이 인권과 사회정의를 추구 해야 함을 강조한다. 둘째는 양성평등을 구현하고 여성의 권리를 증진토록 해야 함을, 셋째 원칙 은 인간중심의 자력화(people-centered empowerment)에 집중해야 함을 제시한다. 넷째 원칙은 시민사회단체들은 자체의 투명성, 개방성 그리고 굿거버넌스를 실행토록 해야 함, 다섯째 원칙은 자치와 지역의 주인의식 그리고 참여를 강화해야 함을 강조한다. 여섯째 원칙은 공평한 파트너십 과 연대를 추구해야 함을 설명하고, 일곱째는 지식과 상호 학습을 창출을, 여덟째 원칙은 지속가 능한 성과를 도출하도록 노력해야 함을 제시하였다.

Open Forum은 CSO 개발효과성 제고와 관련하여 이를 가능하게 하는 환경을 조성(enabling environment)하는 것을 매우 중요하게 다룬다. 지난 이스탄불 세계총회에서는 Open Forum은 특 별히 개도국 정부에 지켜야할 최소한의 5 개의 기준을 제시하였다. 첫째 기준은 독립성과 자체규제 이며, 둘째는 $\mathrm{CSO}$ 에 대한 승인이다. 셋째는 실제로 작동되는 법적체계이고, 넷째는 파트너십과 기술적 지원이다. 마지막 다섯째는 투명성, 개방성 그리고 책임성이다. 이러한 다섯 개의 기준이 개도국에서 $\mathrm{CSO}$ 들이 효과적인 개발활동을 할 수 있도록 개도국 정부가 지켜주어야 할 최소한의 기준이다. 아울러, Open Forum은 선진공여자들에 대한 6가지 기준을 제시하였다. 그 기준들을 구성하는 핵심내용을 보면, 첫째는 $\mathrm{CSO}$ 의 독립성과 자율성 그리고 $\mathrm{CSO}$ 역할의 다양성에 대한 인 정과 지지, 청렴성과 윤리적 실행이다. 둘째 기준은 개발행위자로서의 $\mathrm{CSO}$ 를 지지하는 지속적이 고, 투명하며 일관성 있는 정책, 공여자의 전략에 대한 정보공유, 개도국과 신흥국가에서의 개발 효과성의 주요 추동자로서의 $\mathrm{CSO}$ 에 대한 인식, 지역의 지식과 문화적으로 관련된 역량의 장려, 양성평등과 여성권리 촉진, 공여자 자문그룹의 구성에 참여이다. 셋째 기준은 파트너십을 존중하 는 것으로 $\mathrm{CSO}$ 의 목표와 미션을 존중하는 파트너십 형성과 $\mathrm{CSO}$ 가 수립한 프로그램에 대한 존중 및 직간접적 재정지원이다. 넷째는 $\mathrm{CSO}$ 개발효과성을 위한 재정지원 조건, $\mathrm{CSO}$ 신용기금을 위한 다자간지원 및 재정지원협약에 대한 정부의 적절한 책임성이며, 다섯째 기준은 투명성과 굿거버넌 스이다. 정보에 대한 현지 $\mathrm{CSO}$ 의 접근도 중요하다. Open Forum이 제시하는 마지막 여섯째 기준 은 $\mathrm{CSO}$ 의 정책대화 참여 촉진과 공적 정책개입 활동에 대한 지지이다. 이상의 여섯 개의 원칙들 이 $\mathrm{CSO}$ 개발효과성 제고를 위해 선진공여자가 고려해야할 내용이다. 이는 단순히 CSO들에 대한 재정지원이나 프로그램을 확대하는 수준을 넘어서는 내용이다. $\mathrm{CSO}$ 는 개발협력의 파트너로서 협력 할 것을 정부에게 요구하고 있다.

33) http://www.cso-effectiveness.org/spip.php?page=rubrique\&id_rubrique=49 (2010년 12월 6일 방문) 
Open Forum에서 추진하는 CSO개발효과성은 규모나, 내용면에서 중요한 원조 공여자로 오랫동안 그 역할을 담당하고 있는 $\mathrm{CSO}$ 내부에서 자신의 활동을 기본이 되는 원칙에 대해 성찰하고 개선하 려는 노력을 기울여 효과성 제고에 기여하는 것으로 매우 중요한 시도이다. 이러한 $\mathrm{CSO}$ 의 노력은 바로 시민사회원조의 질을 제고하고, 나아가 정부기구가 담당하지 못하는 역할을 더욱 효과적으로 수행할 것이다.

\section{3) Reality of Aid}

Reality of Aid는 세계 시민사회단체들이 연대와 공정함을 기반으로 빈곤감축을 위한 새롭고 효과 적인 전략을 수립하는데 기여하는 국제적 및 국가적 정책들을 촉진하기 위해 1993년 설립한 네트 워크로 현재 166 개 회원단체사가 참여하고 있다. ${ }^{34)}$

Reality of Aid는 해마다 시민사회의 입장에서 원조정책을 평가하고, 정책적 대안을 제안하는 'Reality of Aid Report'를 발간한다. 2010년 Reality of Aid는 선진국과 개도국 30개국의 36개 시 민사회단체들이 참여하여 작성한 2010년 보고서 'Aid and Development Effectiveness : Towards Human Rights, Social Justice and Democracy'(이하 보고서)를 발간하여 국제사회의 개발원조 에 대해에 비판적인 내용을 주장한다.

Reality of Aid는 현재의 원조효과성이란 기술적인 공여자의 특별 팀, 비교우위분석, 국가환경분 석 및 모니터링조사 작업으로 해석될 뿐이라고 평가한다. 많은 경우 원조효과성 논의는 기존의 원 조체제를 대체하거나 단순화하지 못하고, 그 위에 몇몇 내용을 더하는 정도의 수준이라는 것이다. Reality of Aid는 이러한 현상은 공여자의 통제 하에서 발생하며, 이해당사자간의 관계나 의사결 정의 질 개선을 담보하지 못한다고 지적한다. ${ }^{35)}$ 현 원조효과성 체제에 대한 이러한 상황인식을 기반으로, Reality of Aid에 참여하는 시민사회단체들은 새로운 개혁 의제로 '개발효과성'을 제안 하였다. 이는 빈곤감축과 인권에 기반한 개발의 목표를 달성하기 위한 성과에 집중하는 개념이다. 또한 개발효과성은 개발협력이 물품 및 서비스를 제공하고 높은 소득을 이루는 것뿐 아니라, 사회 경제적 정의의 관점과, 가난한 이들의 역량을 제고하고 소외된 계층이 정책을 형성하고 실행하는 과정에 참여하는 것을 포함하고 있다고 설명한다. ${ }^{36)}$ Reality of Aid의 포괄적인 개발효과성 접근 은 세 개의 중요한 내용을 다루고 있다 첫째는 인권을 존중하고, 가난한 사람들을 자력화 (empowering)하며, 양성평등과 지속가능성을 촉진하는 것이다. 둘째는 연대와 주권 그리고 상호

34) http://www.realityofaid.org/aboutroa/index/id/22/Reality-of-Aid-Profile (2010년 12월 7일 방문)

35) Reality of Aid. 2010. "Aid and Development Effectiveness: Towards Human Rights, Social Justice and Democracy", Reality of Aid 2010 Report. Quezon City: IBON Books, p 15.

36) Reality of Aid. 2010. "Aid and Development Effectiveness: Towards Human Rights, Social Justice and Democracy", Reality of Aid 2010 Report. Quezon City: IBON Books, p 10. 
성에 기반하여 개발 파트너십을 개혁하는 것이다. 셋째는 원조체계의 전환과 개발을 위한 정책일 관성의 담보이다.

Reality of Aid는 이러한 내용을 기본으로 하여 2011년 4차 부산 원조효과성고위급회의에 참여하 는 모든 국가의 정부에 다음의 아홉 개의 사항을 권고한다. 첫째, 국제적인 합의사항에 맞는 충분 한 양의 원조를 무상원조로 공급해야한다. 둘째, 원조 관련 의사결정과 원조관련 자료는 투명해야 한다. 셋째, 수원국 정부가 아닌 가난한 이들에 의한 민주적 주인의식이 담보되어야 한다. 넷째, 원조가 인권협약을 존중하고, 가난하고 취약한 공동체가 자신들의 권리를 요구하는 것을 가능케 하도록 담보할 만한 구속력 있는 수단의 도입이 필요하다. 다섯째, 사회통합과 사회적 부정의에 대한 원조의 영향을 측정해야 한다. 여섯째, 비구속성 원조를 해야 하며, 불평등과 환경적 피해 같은 공공정책의 목표를 고려하는 공공조달 방식을 마련해야 한다. 일곱째, 원조기관이 급증하는 것을 중지해야 한다. 여덟째, 원조분업화 과정이 양성평등이나 환경보호와 같은 중요한 목표를 밀 어내지 못하도록 해야 한다. 아홉째, 개발을 위한 정책 수단들에 대한 강력한 정책일관성을 도입 해야 한다. ${ }^{37)}$ Reality of Aid는 이러한 내용들을 참여하고 있는 Better Aid 활동을 통해 2011년 부산회의에서 현 원조체제에 반영하고자 한다.

현재 세계 시민사회는 보다 효과적으로 빈곤감축을 포함하는 국제개발협력목표들을 달성하기 위해 정부원조기관을 중심으로 하는 기존의 원조행위자와는 다른 식의 접근을 하고 있다. 몇몇 주요 국 제개발 $\mathrm{NGO}$ 들은 전통적으로 집중해서 다루어오던 분야의 이슈에 대해 더욱 혁신적이고 집중적인 투자를 통해 실질적인 성과를 내기위해 노력하고 있다. 그리고 좀 더 진보적인 개발NGO들은 직 접적인 개발과 구호 사업을 수행하는데 있어 권리에 기반하는 접근방식을 활용하여 보다 근본적으 로 문제를 해결하는 방식을 채택하고 있다. 또한 많은 시민사회그룹은 자신들의 개발 사업을 더욱 효과적으로 수행하기 위한 목적으로, 자신들 내부를 성찰하고 또 이를 가능케 하는 정부의 환경조 성을 적극적으로 요구하는 작업도 수행하고 있다. 이와 같은 직접사업수행과 시민사회내부의 성찰 외에, 많은 세계시민사회단체들은 연대체운동 방식으로 원조체제의 개혁을 위해 적극적으로 정책 개입을 하고 있다.

37) Reality of Aid, 'Aid and Development Effectiveness : Towards Human Rights, Social Justice and Democracy' (Quezon City, IBON Books 2010), P 5-25. 


\section{IV. 결론 : 한국시민사회에의 시사점과 과제}

\section{1. 한국 시민사회의 동향}

세계시민사회의 다양한 움직임은 한국 시민사회에 많은 시사점을 준다. 현재 한국 시민사회는 크 게 두 개의 방식으로 국제개발협력에 참여하고 있다. 첫째는 개발 $\mathrm{NGO}$ 를 중심으로 하는 직접적인 개발사업 수행이다. 74 개 개발 $\mathrm{NGO}$ 의 협의체인 한국해외원조단체협의회(이하 해원협)의 자료38)에 의하면 2009년 해원협 회원단체 39$)$ 들의 해외사업의 규모는 172,266 백만원이다. 약 660 명의 한국 개발NGO의 인력이 개도국에서 주로 지역개발(39.4\%), 보건의료(7.2\%), 교육(6.9\%)사업을 중심으로 활발하게 활동하고 있다. ${ }^{40)}$ 둘째 방식으로는 원조정책에 대한 정책개입 운동이다. ODA Watch, 참여연대와 같은 개별NGO와 지구촌빈곤퇴치시민네트워크41), 한국해외언조단체협의회와 같은 시민 사회단체의 연대체가 정책개입 운동을 수행해왔다. 한국 사회에서 각자의 방식으로 국제개발협력 활동을 해온 이들 개발NGO와 시민사회단체들은 2010년 9월 '국제개발협력시민사회포럼(Korean Civil Society Forum for International Development, KoFID)'를 결성하였다. KoFID는 그동안 개발NGO와 일부 시민사회단체 중심으로 진행되던 정책개입운동에 여성, 인권, 환경 및 개발단체 들이 참여하여 본격적으로 국제 시민사회와의 연대를 통해 국제개발협력 정책개입운동을 수행할 준비를 하고 있다. 현재 KoFID는 Better Aid의 한국 운동체(platform)로써 2011년 부산 4차 원 조효과성고위급회의에 효과적으로 대응하기 위해 준비 작업 중이다. 이외에도 개발 $\mathrm{NGO}$ 를 중심으 로 한 30 여개의 $\mathrm{NGO}$ 들은 지난 2010년 3월 'Open Forum 한국 회의'를 개최하여 국제개발협력과 관련한 한국 개발 $\mathrm{NGO}$ 를 포함한 시민사회단체들의 개발효과성을 제고하기 위해 필요한 내부적 점 검42)과 이를 가능케 하는 정부의 환경조성을 위한 제안을 하였다. 또한 ODA Watch는 한국 시민 사회를 대표하여 'Reality of Aid 2010' 보고서에 'Korea Joins the Big League with a Donorcentric Approach'이라는 제목의 한국원조에 대한 의견을 제시하였다. ${ }^{43)}$ 한국시민사회의 국제개 발협력 정책개입운동은 아직 초보적인 단계이지만 점차 기 기본적인 사항들을 갖추며 본격적인 활 동을 해가고 있다.

38) 2010년 발행한 2009년 한국국제개발NGO편람이다.

39) 74 개 회원들 중 설문에 답한 50 개의 단체

40) 신재은, 전지은, "2009년도 한국개발NGO현황" 윤현봉 편, 「2009년 한국국제개발NGO편람」(서울 : 한국해외원조단체 협의회, 2010), pp. 153-175.

41) 2006년 결성된 시민사회단체들의 연대체이다. 개발NGO와 시민사회단체로 구성되어 캠페인과 정책운동을 수행한다.

42) 이 회의에서는 CSO 개발효과성 제고를 위한 원칙, 기준, 환경조성 등의 주제가 논의 되었다.

43) Lee Tae Joo, "Korea Joins the Big League with a Donor-centric Approach" in Reality of Aid (ed.), Aid and Development Effectiveness: Towards Human Rights, Social Justice and Democracy'(Quezon City, IBON Books 2010), pp. 233-236. 


\section{2. 세계시민사회 활동으로부터의 시사점}

세계 시민사회는 국제개발협력과 관련한 직접개발사업 수행 및 정책개입운동에 대한 오랜 역사와 전통 및 다양하고 전문적인 방법론을 가져왔다. 따라서 동 분야에서 약 20 여년 미만의 경험을 가 진 한국 시민사회가 얻어야 할 교훈이 많이 있다. 이러한 맥락에서, 한국 시민사회가 세계시민사 회의 국제개발협력 운동으로부터 얻을 수 있는 두 가지 시사점을 정리해 본다.

첫째, 빈곤감축을 위한 보다 전향적인 접근이 필요하다. 한국 개발 $\mathrm{NGO}$ 들은 지역개발, 교육, 보건 의료, 아동결연 등의 직접적인 개발사업수행을 통해 빈곤감축에 기여 한다. 이들의 사업은 주로 개도국 주민들의 기본적 욕구를 충족하는 사회개발 및 인간개발의 방식을 따른다. 그러나 개발 $\mathrm{NGO}$ 가 이러한 개발사업을 수행할 시, 실제로 어떻게 가난한 이들의 권리를 존중하고 이를 기반 하는 방식으로 하는 지는 의문이다. 아주 일부 국제개발NGO의 한국운동체 및 자생적인 한국개발 $\mathrm{NGO}$ 가 이러한 개념을 인식하고 있지만, 전반적으로는 매우 낮선 개념이다. 국제사회에서는 OXFAM, Action Aid와 같은 대형 개발NGO들이 '권리에 기반하는 접근방식'을 기본으로 다양한 개발 사업 을 수행하고 있다. 이는 NGO가 정부간원조기구나 국제기구와 빈곤감축울 위한 사업수행에 있어 다른 접근법이다. OXFAM, Action Aid, World Vision은 사업 목적과 내용에 빈곤감축 이외에 부 정의(injustice)해결을 설정하고 있다. 즉 이들은 가난한 이들의 빈곤의 문제를 단순한 '결핍'으로 보지 않고 '정의'의 문제 즉 구조적인 문제로 보고 있는 것이다. 따라서 이를 보다 근본적으로 해 결하기 위해서 인권과 거버넌스의 문제로 접근하고 결국 원조로 대변되는 현 국제개발협력체제에 대한 개혁을 위한 정책개입운동에 참여하는 것이다. 이러한 내용은 국제개발협력에 대한 정책개입 운동에는 관심을 적게 두고 빈곤감축을 위한 직접적인 개발사업에 집중하는 경향을 가진 한국 개 발NGO들에 대한 많은 점을 시사해 준다.

한국 개발 $\mathrm{NGO}$ 들은 사업수행 및 관리방식의 효율성을 추구하고 효과적인 방법론을 개발하는 것에 노력을 쏟는 것 이외에, 빈곤과 이를 해결하기 위한 노력에 대해 보다 깊고 다양한 인식을 갖고, 이를 구체적인 사업에 적용 하도록 노력해야 한다. 또한 '권리에 기반하는 접근' 방식과 같은 보다 근본적인 관점으로 빈곤감축에 접근하고, 정책개입운동과 같은 구조적인 접근방식을 도입하기 위 해 노력해야 한다.

둘째, 국제개발협력 정책에 대한 한국시민사회의 전문적이고 실질적인 정책개입운동이 필요하다. 세계의 주요 시민사회단체들은 오래전부터 원조체계의 문제를 인식하고, 이를 개혁하여 지구촌의 빈곤층의 문제를 보다 실질적으로 해결하기 위한 전문적인 운동을 다차원적으로 전개해 왔다. 이 를 위해 각국 정부원조기구와 국제개발기구들의 원조의 행태를 전문적으로 분석하고 대안마련을 
위해 노력해왔다. 이에 반해 한국 시민사회는 오랜 시간 동안 민주화실현, 인권개선, 여성권리, 환 경보호, 노동 및 통일 등 국내의 이슈에 집중해 왔다. 이에, 그동안 쌓아온 한국 시민사회운동의 역량을 국제개발협력에서 발휘하고자 할 때 경험과 전문성 그리고 관심의 부족이라는 난관에 부딪 치고 있는 것이다. 지난 2008년 가나 아크라에서 개최된 3차 원조효과성고위급회의에 한국의 시 민사회에서는 단 한명도 참여하지 못한 것은 이러한 현상을 잘 반영하고 있다. 지난 10 월 한국 시 민사회는 지구촌빈곤퇴치시민네트워크를 중심으로 국제시민사회와 연대하여 G20정상회담에 정책 대응하는 경험을 가졌다. 이러한 노력에도 불구하고, 다가올 2011년 부산 4차 원조효과성고위급회 의에서 한국시민사회는 전문성과 경험의 부족으로 핵심적인 정책개입운동에는 참여치 못하고, 국 제시민사회가 활동을 잘 할 수 있도록 환경을 조성해 주는 데에만 역량을 발휘할까 우려된다. 이 에 한국 시민사회는 원조효과성과 개발효과성 이슈 그 자체와 정책개입운동 방식에 대한 전문성을 확보토록 노력해야 한다. 이를 통해, 개도국의 빈곤감축과 개발을 위해 실행되는 원조를 포함한 다양한 정책들이 보다 효과적으로 집행되어 빈곤과 부정의가 사라지는 것에 실질적으로 기여해야 한다. 


\section{참고 문헌}

\section{1. 국내문헌}

김혜경. 「국제시민사회 이슈와 한국시민사회의 대응과제」. 제 5 회 지구촌포럼 자료 ODA Watch.

신재은, 전지은, "2009년도 한국개발NGO현황” 윤현봉 편, 「2009년 한국국제개발 NGO편람」

(서울 : 한국해외원조단체협의회, 2010)

\section{2. 국외문헌}

Action Aid, RIGHTS TO END POVERTY ACTION AID INTERNATIONAL STRATEGY 2005/2010 (Johannesburg: Action Aid, 2005)

Bebbington, Hickey and Mitlin, Can NGOs Make a Difference?, The Challenge of Development Alternative." In Can NGOs Make a Difference?, ed. Bebbington, Anthony., J. Samuel Hickey and Diana C. Mitlin. (New York: Zed Books LTD 2008),

Better Aid, "Development Cooperation : Not Just Aid.”. (Better Aid 2010)

Better Aid, "Development effectiveness in development cooperation: a rights-based perspective" (Better Aid 2010)

Clark. John, Democratizing Development: The Role of Voluntary Organizations (Connecticut: Kumarian Press. 1991)

Finn Trap, “Aid and Development”. SWEDISH ECONOMIC POLICY REVIEW 13.

Lee Tae Joo, "Korea Joins the Big League with a Donor-centric Approach" "in Reality of Aid (ed.), Aid and Development Effectiveness: Towards Human Rights, Social Justice and Democracy'(Quezon City, IBON Books 2010)

Lewis. David. "Development NGOs and the Challenge of Partnership: Changing Relations between North and South." Social Policy \& ADMINISTRATION. Vol 32, No.5, (1998 December) 
Lewis David., and Nazneen Kanji, Non-Governmental Organizations and Development (NewYork: Routledge, 2009),

Roger C. Riddle. Does Foreign Aid Really Work? (New York : Oxford University. 2007)

Save the Children. 2009. Save the Children International Annual Review 2009.

OECD, Shaping the 21st Century :The Contribution of Development Cooperation. (Paris : OECD, 1996)

OXFAM, Demanding Justice. (London : OXFAM 2007)

\section{3. 인터넷 자료}

http://siteresources.worldbank.org/ACCRAEXT/Resources/4700790-1217425866038/AAA-4-S EPTEMBER-FINAL-16h00.pdf (2010년 11월 30일 방문)

http://www.savethechildren.net/alliance/what_we_do/campaign.html (2010년 11월 30일 방문) http://www.oxfam.org(2010년 11월 30일 방문)

http://www.actionaid.org/main.aspx?PageID=2 (2010년 11월 30일 방문)

https://www.worldvision.or.kr/html/worldvision/mind01.asp (2010년 11월 30일 방문)

홍지영, ODA Watch Letter.

http://www.odawatch.net/?mid=articlesth\&page=2\&document_srl=7297 (2010년 12월 1일 방문) http://www.cso-effectiveness.org/spip.php?page=rubrique\&id_rubrique=49 (2010년 12월 6일 방문) 김나리, $\mathrm{ODA}$ Watch Letter 11호,

http://www.odawatch.net/?mid=articlesth\&sort_index=readed_count\&order_type=asc\&page=5 \&document_srl=1184 (2010년 12월 3일 방문)

http://www.wvi.org/wvi/WVIAR2009.nsf/maindocs/D6DC795AC6FCFAA7882576DB007FC4 
http://www.wvi.org/wvi/WVIAR2009.nsf/maindocs/D6DC795AC6FCFAA7882576DB007FC4 2D?opendocument (2010년 12월 7일 방문)

https://childhealthnow.com/docs/en/child-health-now-report.pdf (2010년 12월 7일 방문) http://www.realityofaid.org/aboutroa/index/id/22/Reality-of-Aid-Profile (2010년 12월 7일 방문) 